\title{
PEMANFAATAN KOPERASI SEKOLAH SEBAGAI SUMBER BELAJAR IPS PADA SMP NEGERI 3 BANJAR
}

\author{
Kadek Devi Laviani ${ }^{1}$, lyus Akhmad Haris ${ }^{2}$, Anantawikrama Tungga Admaja ${ }^{3}$ \\ Program Studi Pendidikan IPS Universitas Pendidikan Ganesha Singaraja \\ e-mail: Devi.mertha@gmail.com¹, Akhmad.haris@undiksha.ac.id², \\ anantawikramatunggaatmadja@gmail.com³.
}

\begin{abstract}
Abstrak
Penelitian ini dilaksanakan di SMP Negeri 3 Banjar dengan tujuan (1). menjelaskan nilai-nilai yang ditanamkan dalam koperasi sekolah sebagai sumber belajar IPS, (2). pemanfaatan koperasi sekolah dapat meningkatkan kreativitas siswa di SMP Negeri 3 Banjar, dan (3). koperasi sekolah bermanfaat sebagai sumber belajar IPS dalam pengembangan materi pembelajaran IPS kelas VII di SMP Negeri 3 Banjar. Penelitian ini merupakan penelitian pengembangan (Research and Development) dengan tahapan sebagai berikut Tahap Define, Design dan Develop. Hasil penelitian menunjukkan bahwa 1). Nilai-nilai perkoperasian sudah ditanamkan siswa di SMP Negeri 3 Banjar dalam proses pembelajaran IPS. 2) Hasil validasi draf produk menunjukkan bahwa bahan ajar yang disusun memiliki kelayakan dari ahli materi dan praktisi guru dengan persentase keseluruhan sebesar $77,27 \%$. Berdasarkan hasil tersebut, pengembangan handout materi yang memanfaatkan koperasi sekolah sebagai sumber materi ajar IPS layak digunakan, dan 3). Hasil pengamatan dari keseluruhan indikator menunjukkan kreativitas siswa belum mencapai kriteria keberhasilan yang diinginkan dalam siklus 1 . Hasil persentase yang diperoleh dari pengamatan kreativitas siswa masih kurang dari $76 \%$ yaitu $74,95 \%$, sehingga belum mencapai kriteria keberhasilan yang diinginkan. Berdasarkan hasil observasi keaktifan siswa pada siklus II, menunjukkan bahwa pada setiap indikator kreativitas siswa pada setiap pertemuan sudah mengalami peningkatan dalam indicator keberhasilan yang telah ditetapkan sebesar $\geq 76 \%$. Hasil persentase untuk keseluruhan indikator kreativitas menunjukkan rata-rata kreativitas siswa pada siklus II sebesar $87,81 \%$.

Kata kunci: Koperasi Sekolah, Sumber Belajardan Kreativitas
\end{abstract}

\section{Abstrak}

This research was conducted at the State Junior High School 3 Banjar with the aim (1). explain the values instilled in cooperative schools as a source of social studies learning, (2). the use of cooperative schools can improve the creativity of students in the Banjar 3 Junior High School, and (3). cooperative schools are useful as a source of social studies learning in the development of social studies learning materials in class VII at the 3 Banjar State Junior High School. This research is development research (Research and Development) with the following stages: Stage Define, Design and Develop. The results of the study show that 1). Cooperative values have been instilled by students in the State Junior High School 3 Banjar in the social studies learning process. 2) The results of the product draft validation show that the instructional materials prepared have the feasibility of material experts and teacher practitioners with an overall percentage of $77.27 \%$. Based on these results, the development of material handouts that utilize school cooperatives as a source of teaching material for Social Sciences is appropriate to use. and 3). The results of observations of all indicators show the creativity of students not yet achieving the desired success criteria in cycle 1. The percentage results obtained from observing students' creativity are still less than $76 \%$, namely $74.95 \%$, so that they have not reached the desired success criteria. Based on the observation results of student activity in the second cycle, it shows that on each indicator of creativity students at each meeting have experienced an increase in the indicator of success that has been set at $\geq 76 \%$. The percentage results for the overall indicator of creativity showed that the average creativity of students in the second cycle was $87.81 \%$.

Keywords: School Cooperatives, Learning Resources and Creativity 


\section{PENDAHULUAN}

Di Indonesia koperasi berperan sebagai bagian dari pembangunan dalam rangka mengentaskan kemiskinan. Peran Koperasi sebagai wadah ekonomi rakyat dan soko guru ekonomi nasional kian hari semakin pudar dalam perekonomian Indonesia yaitu untuk mewujudkan masyarakat yang adil, makmur, dan sejahtera sebagaimana amanat UUD 1945.

Sebagaimana kondisi makro nasional akhir-akhir ini tercatat koperasi di Kabupaten Buleleng, Provensi Bali banyak mengalami kebangkrutan atau sudah tidak berkembang. Hal ini terungkap dalam laporan yang disampaikan oleh kepala Dinas Koperasi dan usaha kecil menengah (UKM) Kabupaten Buleleng. Koperasi di Buleleng yang sudah berdiri selama bertahun-tahun sesuai regulasi wajib melaksanakan RAT. Namun, kondisi dilapangan baru sebanyak 184 koperasi yang melaksanakan RAT per tahun. Sedangkan masih terdapat 22 koperasi yang belum melaksanakan rapat hingga saat ini. Tercatat ada 308 koperasi di Buleleng yang wajib melaksanakan RAT sebanyak 206. Hanya saja sesuai regulasi yang ada, mereka wajib melaksanakan RAT. 52 koperasi yang masuk kategori sakit di Buleleng utamanya dipicu masalah keuangan, namun ada pula tersandung manajemen dan keterbatasan sumber daya manusia (SDM) didalamnya hingga mengakibatkan koperasi tersebut tidak bisa berjalan dengan baik.

Oleh karena itu perlu adanya upaya pemerintah untuk mendorong munculnya lembaga-lembaga pendidikan baik negeri maupun swasta untuk mencetak dan mendidik sumber daya manusia yang memiliki kecakapan dan pengetahuan dalam bidang koperasi, termasuk melakukan revisi atas kurikulum pendidikan menengah pertama dalam pemberian materi tentang perkoperasian dan memanfaatkan koperasi sekolah sebagai sumber belajar IPS sehingga siswa lebih aktif dan kreatif dalam mempelajari manajemen perkoperasian.

Koperasi sekolah dapat dimanfaatkan sebagai sumber belajar IPS oleh siswa kelas VII dengan sub Materi Uang Dan Lembaga Keuangan khususnya sub bahasan koperasi.Dengan belajar tentang perkoperasian siswa dapat lebih aktif untuk mengetahui tentang manajemen koperasi, pengelolaan koperasi, sistem keuangan koperasi dan lain sebagainya. Namun pada kenyataannya koperasi sekolah hanya dimanfaatkan siswa untuk membeli barang-barang kebutuhan sekolah. Dalam pembelajaran IPS lebih banyak siswa mengetahui atau memahami konsep materi yang diajarkan tetapi siswa tidak mempraktekkan secara langsung dalam kehidupan sehari-hari, karena akibat dari guru dalam proses belajar mengajar lebih banyak menggunakan metode konvensional seperti ceramah yang cendrung siswa pasif dan hasil belajarnya ada pada ranah kognitif tingkat rendah, padahal pendidikan IPS ditingkat SMP harus tertanam sikap-sikap sosial dan ketrampilan-ketrampilan sosial yang mana sikap dan ketrampilan siswa tersebut akan diperoleh apabila siswa dilibatkan secara langsung dalam kegiatan praktis yang bersumber dari aktivitas sosial dimana siswa belajar.

Berdasarkan penelusuran penelitian pada Koperasi Sekolah di SMP Negeri 3 Banjar ditemukan permasalahan-permasalahan yang sangat ekuivalen dan fundamental pada pembelajaran IPS, yaitu diantaranya:

1) Materi pada buku teks yang digunakan oleh guru pada mata pelajaran IPS belum memberikan ruang dari segi substansi dan evaluasi bagi guru dan murid untuk mengeksploitasi atau mengembangkan nilai-nilai pendidikan yang bersifat kedaerahan (local genius) pada materi pembelajaran IPS. Contoh nya dalam buku "Kementrian Pendidikan dan Kebudayaan. 2014. IImu Pengetahuan Sosial. Jakarta: Kemendikbud".

2) Metode Metode yang digunakan setiap pembelajaran IPS masih bersifat konvesional dan masih kaku, yaitu dengan menggunakan metode ceramah bervariasi karena perubahan kurikulum seiring perkembangan zaman terus berubah-ubah sehingga hal ini menyebabkan tuntutan agar siswa lebih aktif lagi yang didukung oleh peran guru sebagai mediator sangat penting dalam peningkatan prestasi siswa.

3) Belum adanya pemanfaatan atau sinergi daripada tenaga pendidik (guru) dalam membina peserta didiknya melalui berinovasi, berkreasi dan berpikir kritis, tentang lingkungan sosial masyarakat. Misalnya dalam masalah ini siswa hanya memanfaatkan koperasi sekolah untuk membeli kebutuhan sekolah dan tidak memanfaatkan koperasi sekolah sebagai sumber 
belajar IPS sehingga perlu dilakukan observasi secara langsung ke koperasi sekolah yang bertujuan memberikan mengajarkan siswa lebih aktif dan menciptakan ketrampilan berpikir maupun berwirausaha mengenai pengelolaan koperasi, manajemen koperasi, keuangan koperasi.Penggunaan media dan sumber pembelajaran yang relevan dalam pembelajaran IPS masih kurang dipahami secara menyeluruh oleh tenaga pendidik (guru).

4) Hasil evaluasi belajar siswa menjadi menurun karena guru hanya menggunakan metode ceramah sehingga menghasilkan siswa yang pasif dan berpedoman pada teori yang diajarkan.

Dari paparan tersebut peneliti tertarik untuk melakukan penelitian tentang Pemanfaatan Koperasi Sekolah Sebagai Sumber Belajar IPS pada SMP Negeri 3 Banjar.

\section{METODE PENELITIAN}

Penelitian ini menggunakan model penelitian dan pengembangan pendidikan (Educational Research and Develop). Pengembangan yang dilaksanakan adalah pengembangan model pembelajaran dengan pemanfaatan Koperasi Sekolah sebagai sumber belajar IPS di SMP Negeri 3 Banjar. Materi ajar dikembangkan dalam bentuk materi handout dengan berdasar pada model 4-P yakni pendefinisian, perancangan, pengembangan dan penyebaran (Sanjaya, 2013).

1. Tahap pendefinisian (define)

Pada tahap pendefinisian ini dilakukan analisis melalui : (1) Studi pustaka, dilakukan untuk mengetahui kurikulum yang digunakan di SMP Negeri 3 Banjar, perangkat pembelajaran yang digunakan guru, serta mengkaji materi koperasi sekolahdan (2) Studi empirik, dilakukan untuk mengetahui jumlah guru IPS, sumber dan bahan ajar IPS yang digunakan oleh masing-masing guru, dan minat peserta didik terhadap pelajaran IPS.

2. Tahap perancangan (Design)

Pada tahap perancangan (design), dilakukan rancangan terkait: (1) Draf handout materi ajar IPS dan RPP tentang pengembangan nilai-nilai perkoperasian. (2). Format handout materi ajar IPS dan RPP. (3). Format penilaian kognitif siswa, lembar uji judges dan lembar uji praktisi guru.

3. Teknik pengembangan (Develop)

Pada tahap ini dilaksanakan pengembangan materi IPS dengan pemanfaatan koperasi sekolah sebagai materi handout materi ajar IPS. Pengembangan materi ini dilaksanakan pada sub tema Koperasi Indonesia dan Koperasi Sekolah, dengan kompetensi inti (KD) mengidentifikasi koperasi dan manjemen koperasi dan pengaruhnya terhadap kehidupan sosial, ekonomi dan nilai normaserta kelembagaan sosial budaya. Hasil pengembangan berupa handout materi ajar akan diuji dengan sistem uji coba terbatas yang berdasar pada model penelitian tindakan kelas (PTK) dengan empat langkah yaitu perencanaan, pelaksnaan, pengamatan dan refleksi.

4. Tahap uji ahli

Subjek uji coba pada tahap ini adalah seorang ahli isi, media dan desain handout pembelajaran IPS. Ahli isi, media dan desain handout dan RPP pembelajaran IPS dalam penelitian pengembangan ini adalah seorang doktor Pendidikan IPS yaitu Dr. Drs. I Putu Sriartha. M.S Sedangkan validator Handout dan RPP adalah seorang doctor Pendidikan IPS di Universitas Pendidikan Ganesha Singaraja yaitu Dr Nengah Swastika, M.Pd.

5. Tahap uji eksperimen

Pada tahap ini, uji coba pertama terdiri dari 8 kelas, namun dicari 2 kelas yang setara melaui Uji-T dengan pertimbangan data nilai Ujian tes kognitif. Kemudian dari 2 kelas tersebut dibedakan kelas yang akan diberikan suplemen materikoperasi sekolah dan tidak diberikan suplemen materikoperasi sekolah. kelas yang akan diberikan suplemen materikoperasi sekolah akan diberikan Handout berupa bahan ajar yang sudah teruji vaiditasnya oleh para ahli, dari masing-masing 2 anggota kelas akan dipilih secara random sampling, anggota yang akan dijadikan sampel penelitian. Kemudian setelah pemberian suplemen materikoperasi sekolah dilakukan penilaian hasil belajar siswa. Kemudian dilakukan perbandingan hasil belajar untuk menguji komponen pengembangan bahan ajar IPS terhadap minat belajar siswa. 
Populasi dan sempel penelitian Populasi dalam penelitian ini adalah seluruh siswa kelas 7 di SMP Negeri 3 Banjar. Terdapat 8 kelas dengan total jumlah siswa 272 orang. Sampel dalam penelitian ini yaitu sampling kelas dengan dipilihnya 2 kelas, yaitu kelas eksperimen/ treatment dan kelas control. Agar dapat memilih 2 kelas tersebut, dilakukan uji kesetaraan kelas terlebih dahulu dengan T-test untuk menemukan pasangan kelas yang setara, agar dapat menemukan 2 kelas yang setara maka akan dipilih secara random sampling. Data yang akan digunakan adalah data nilai UAS (Ulangan Akhir Semester) atau UTS (Ulangan Tengah Semester) siswa.

Pada bagian ini, dideskripsikan mengnai metode pengumpulan data yang diklasifikasikan menjadi dua yaitu 1). Metode pengumpulan data pada tahap studi tentang koperasi dan 2) tahap define, design dan develop.

Penelitian ini menggunakan dua teknik analisis data yaitu teknik analisis data deskriptif kualitatif, dan deskriptif kuantitatif.

1. Analisis Kualitatif

Dalam penelitian tahap pertama dan tahap kedua (define dan design), menggunakan metode analisis deskriptif kualitatif. Data-data yang diperoleh dari studi dokumentasi, observasi dan wawancara akan dideskripsikan sehingga diperoleh istilah-istilah, konsepkonsep, pengertian dan contoh-contoh (Sugiyono, 2010). Berdasarkan hasil analisis tersebut, peneliti kemudian memberikan interpretasi dan makna yang relevan untuk pengembangan materi pembelajaran IPS yang ditawarkan. Teknik analisis deskriptif kualitatif ini digunakan untuk mengolah hasil wawancara dan obsevasi dengan guru IPS dan peserta didik terkait kondisi pembelajaran IPS di SMP Negeri 3 banjar dan kreativitas belajar siswa. Sedangkan data hasil validasi ahli dosen dan praktisi guru, review ahli isi, media dan desain pembelajaran IPS serta masukan dari guru IPS Kelas VII, dikelompokkan untuk mengetahui masukan, tanggapan, saran dan kritik terhadap pengembangan produk bahan ajar handout, RPP dan hasil belajar yang dikembangkan. Hasil analisis data ini kemudian digunakan untuk merevisi produk bahan ajar handout, RPP dan hasil belajar

\section{Analisis Kuantitatif}

Analisis data tahap develop dilakukan menggunakan statistik deskriptif. Data angket penilaian dari uji ahli dosen dan praktisi guru, uji ahli isi, media dan design pembelajaran IPS, dianalisis dengan teknik mengolah data yang diperoleh mealui angket dalam bentuk deskriptif persentase. Rumus yang digunakan untuk menghitung persentase dari masingmasing subjek adalah sebagai berikut.

\begin{tabular}{|c|c|c|c|}
\hline & $\begin{array}{l}\text { Tingkat } \\
\text { Pencapaian } \\
\text { (\%) }\end{array}$ & Kualifikasi & Keterangan \\
\hline & $90-100$ & $\begin{array}{l}\text { Sangat } \\
\text { Baik }\end{array}$ & Tidak perlu revisi \\
\hline & $75-89$ & Baik & Sedikit revisi \\
\hline & $65-74$ & Cukup & $\begin{array}{l}\text { Direvisi } \\
\text { secukupnya }\end{array}$ \\
\hline & $55-64$ & Kurang & $\begin{array}{l}\text { Banyak hal yang } \\
\text { direvisi }\end{array}$ \\
\hline & $0-54$ & $\begin{array}{l}\text { Sangat } \\
\text { Kurang }\end{array}$ & $\begin{array}{l}\text { Ulangi membuat } \\
\text { produk }\end{array}$ \\
\hline \multicolumn{4}{|c|}{ persentase $=\frac{\sum x}{\text { skormaksimal ideal (SMI) }} \times 100 \%$} \\
\hline $\begin{array}{l}\text { Keterangan: } \\
\mathrm{P}=\text { persentase } \\
\sum=\text { jumlah } \\
\text { SMI= Skor mak }\end{array}$ & & & \\
\hline
\end{tabular}

Selanjutnya analisis untuk menghitung persentase keseluruhan subjek digunakan rumus persentase sebagai berikut. 


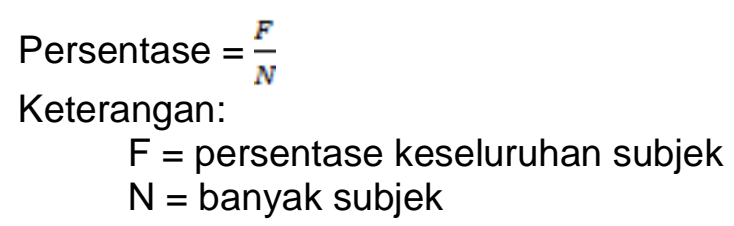

Untuk dapat memberikan makna dan pengambilan keputusan digunakan ketetapan sebagai berikut.

Tabel: Konversi tingkat pencapaian dengan skala 5

(Tegeh dan Kirna (2010) dalam Premana, 2013: 77)

Draf instrumen minat hasil belajar yang telah disusun, didiskusikan dengan ahli (expert judgement) dengan tujuan untuk memperoleh masukan mengenai instrumen yang disusun telah mencerminkan materi yang diukur karena masukan yang diberikan melalui instrumen sangat berarti untuk kesempurnaan pengembangan bahan ajar IPS pada handout. Validasi terhadap minat belajar dilakukan oleh dua orang pakar untuk mengetahui kesahihan isi (content validity). Sebagai ahli isi untuk instrumen tes minat belajar adalah satu orang dosen pascasarjana dan satu orang guru IPS kelas VII yang bertugas di SMP Negeri 3 Banjar. Kedua pakar tersebut diberikan format penilaian yang berisi duaalternatif penilaian yakni relevan dan tidak relevan dengan mengisi tanda rumput pada kolom yang telah disediakan. Uji validitas menggunakan rumus Gregory dengan perhitungan sebagai berikut.

1) Kedua pakar diminta menilai tingkat relevansi instrument pada setiap butir dengan menggunakan skala 1-2-3-4.

1) Skala kuesioner dikelompokkan menjadi dua, yaitu 1) skor 1 dan 2 dikelompokkan menjadi kelompok kurang relevan; dan 2) skor 3 dan 4 dikelompokkan menjadi kelompok sangat relevan.

2) Hasil penilaian kedua pakar ditabulasi dalam bentuk matriks.

Tabel: Tabulasi Matriks

\begin{tabular}{llll}
\hline \multicolumn{2}{c}{ Penilai 1 } & \multicolumn{2}{c}{ Penilai 2 } \\
\hline Tidak Relevan & Relevan & Tidak Relevan & Relevan \\
(Skor 1-2) & (Skor 3-4) & (Skor 1-2) & (Skor 3-4)
\end{tabular}

4). Dibuat tabulasi silang untuk kedua penilaian sebagai berikut. Untuk menentukan koefisien validitas isi, hasil penilaian kedua orang pakar dimasukkan ke dalam Tabel Gregory, yaitu tabulasi silang $2 \times 2$ yang terbagi menjadi sel A, B, C, dan D seperti Tabel berikut ini:

Tabel: GregoryExpert Judges Minat Belajar

\begin{tabular}{llll}
\hline & & $\begin{array}{l}\text { Penilai I } \\
\text { Tidak Relevan } \\
\text { (Skor 1-2) }\end{array}$ & $\begin{array}{l}\text { Relevan } \\
\text { (Skor 3-4) }\end{array}$ \\
\hline \multirow{2}{*}{$\begin{array}{ll}\text { II } \\
\text { II }\end{array}$} & $\begin{array}{l}\text { Tidak Relevan } \\
\text { (Skor 1-2) }\end{array}$ & A & B \\
\cline { 2 - 3 } & $\begin{array}{l}\text { Relevan } \\
\text { (Skor 3-4) }\end{array}$ & C & D \\
\hline
\end{tabular}

(Candiasa, 2010)

5) Menghitung validitas isi (validity content) dengan rumus berikut.

$V C=\frac{D}{A+B+C+D}$

Keterangan:

D: Kedua judges setuju

C: Judges I tidak setuju, judges II setuju

B: Judges I setuju, judges II tidak setuju

A: Kedua judges tidak setuju

Jika hasil perhitungan validitas isi lebih dari 0,70 maka angket layak digunakan sebagai instrument penelitian dan sebaliknya jika hasil perhitungan validitas isi kurang dari 0,70 maka tes tidak layak digunakan. Butir angket yang kurang relevan akan dibuang jika keterwakilan butir angket sudah memadai secara proporsional materi atau sub materi yang 
sudah diajarkan. Butir angket yang kurang relevan akan direvisi apabila butir angket tersebut belum mewakili secara proporsional pada materi atau sub materi yang diajarkan.

\section{HASIL DAN PEMBAHASAN}

\section{Nilai-Nilai yang Ada Dalam Kehidupan Perkoperasian Sekolah Di SMP Negeri 3 Banjar}

Nilai-nilai koperasi sudah tertanam pada siswa di koperasi SMP Negeri 3 Banjar. Hal ini dibuktikan dari nilai menolong diri sendiri, nilai kejujuran dan keterbukaan dan nilai solidaritas sudah dilakukan oleh siswa dalam perkembangan koperasi sekolah demi kepentingan bersama. Koperasi sekolah SMP Negeri 3 banjar dibangun untuk membantu para siswa dalam memenuhi kebutuhannya dan mampu menerapkan nilai-nilai dan mampu diterapkan dalam kehidupan bermasyarakat. Koperasi sekolah smp negeri 3 banjar memiliki fasilitas yang cukup lengkap dalam menunjang siswa untuk memenuhi kebutuhannya.

\section{Pemanfaatan koperasi sekolah dapat meningkatkan kreativitas siswa di SMP Negeri 3 Banjar}

Pengukuran kreativitas siswa yang dilakukan dengan menggunakan observasi kreativitas siswa pada siklus I menunjukkan hanya 11 aspek kreativitas yang belum mencapai kriteria keberhasilan seperti rasa ingin tahu siswa dalam proses pembelajaran masih rendah, hal ini dapat dilihat ketika guru selesai memberikan materi, jumlah siswa yang bertanya hanya sedikit, siswa juga tidak berusaha mencari referensi dari buku lain ketika diskusi berjalan, mereka hanya mengandalkan handout yang diberikan oleh peneliti. Siswa kurang mengajukan pertanyaan yang kreatif dilihat dari banyak siswa yang bertanya sudah ada dibuku maupun di handout yang diberikan oleh peneliti. Siswa yang mau mengemukakan pendapat juga masih kurang begitu baik, ketika mengemukakan pendapat, mereka terlihat masih malu-malu dan kurang percaya diri. Pendapat yang mereka berikan juga tidak berdasarkan hasil pemikiran sendiri, mereka masih terpengaruh oleh temannya dalam memberikan pendapat. Daya imajinasi siswa pada siklus 1 juga masih kurang baik, hal ini dapat dilihat ketika pembuatan flip chart, siswa masih belum bisa mendiskripsikan secara detail materi yang diberikan oleh peneliti. Hal ini menjadi kesulitan bagi mereka karena dalam pembelajaran sehari-hari guru kurang melatih siswa dalam mendiskripsikan hasil materi, siswa hanya dituntut untuk dapat mengerjakan soal dan mempresentasikan dari materi yang telah diajarkan melalui buku, sehingga menyebabkan siswa kurang dalam mengelola ide untuk dituangkan dalam sebuah flip chart. Selain itu, siswa dalam mengembangkan suatu gagasan terlihat masih rendah, hal ini dapat diketahui ketika presentasi di depan, hanya ada beberapa siswa yang mampu mempresentasikan dan menjelaskan dengan baik hasil diskusinya. Sedangkan yang lain hanya diam karena tidak dapat mengembangkan gagasannya.

Pada siklus II semua aspek kreativitas siswa telah mengalami peningkatan dan dapat melebihi kriteria keberhasilan. Rasa ingin tahu siswa sudah meningkat, siswa sudah mulai menggunakan sumber belajar yang lain karena mereka menyadari bahwa tidak semua materi terlampir pada handout yang diberikan oleh guru sehingga mereka harus mencari referensi lain untuk menyelesaikan tugas diskusi. Sikap rasa ingin tahu siswa juga dapat dilihat pada siklus II dengan semakin meningkatnya jumlah siswa yang mau bertanya tanpa harus ditunjuk terlebih dahulu. Pertanyaan yang mereka ajukan bukan hanya kepada guru namun juga kepada teman diskusi atau teman kelompok yang lain ketika mereka presentasi. Siswa juga sudah mulai aktif dalam memberikan pendapat kepada guru atau kepada teman diskusi ketika presentasi. Latihan yang dilakukan pada siklus I dalam pembuatan flip chart mampu meningkatkan daya imajinasi siswa pada siklus II, siswa sudah dapat menuangkan ide-ide mereka dalam sebuah flip chart hal ini dapat dilihat pada hasil flip chart siklus II lebih bagus dan lebih lengkap materi yang di tuangkan. Siswa juga sudah mampu berinovasi dengan baik terlihat dalam flip chart yang mereka buat sudah berbeda dari kelompok yang lain dan hasilnya lebih menarik serta lebih berwarna daripada hasil flip chart pada siklus I yang lebih sederhana. Siswa juga sudah mampu dalam mengembangkan gagasannya, hal ini dapat terlihat ketika proses diskusi dan presentasi sudah banyak yang memberikan 
gagasan atau usul. Siswa terlihat bersemangat dan berlomba-lomba untuk menampilkan yang terbaik pada kelompoknya.

Meningkatnya kreativitas siswa dari siklus I ke siklus II dikarenakan telah dilakukan perbaikan dari kekurangan yang terjadi pada siklus I. Guru melakukan upaya-upaya untuk meningkatkan kreativitas siswa, diantaranya adalah: 1) memilih topik masalah yang mampu mengajak siswa untuk kreatif dan berpikir luas dalam menyelesaikan suatu permasalahan. Guru memberikan beberapa pertanyaan yang harus didiskusikan oleh setiap kelompok dan mencari jawaban dari pertanyaan tersebut. 2) menggunakankaterampilan-keterampilan dalam pemecahan masalah dengan memberikan lembar diskusi kelompok dan proyek kelompok. Dalam hal ini guru melatih siswa untuk bersikap percaya diri terhadap gagasan yang dikemukakan oleh setiap siswa dan mengajak siswa untuk menghargai setiap pendapat yang dikemukakan oleh temannya, sehingga siswa tidak malu-malu lagi dalam berpendapat ataupun bertanya. Upaya yang dilakukan guru ini dapat meningkatkan aspek kreativitas siswa yaitu meningkatnya rasa ingin tahu siswa, berkembangnya gagasan yang dimilki oleh siswa dan tidak malumalu lagi dalam berpendapat serta mampu mengajukan gagasan yang berbeda dengan orang lain; 3) mengikutsertakan siswa dalam menyusun kegiatan pembelajaran dengan berdiskusi kelompok mengenai permasalahan yang diberikan oleh guru dan memberikan proyek yang harus diselesaikan secara berkelompok serta membagi penugasan yang harus dikerjakan oleh masing-masing anggota kelompok. Upaya yang dilakukan guru ini mampu meningkatkan aspek kreativitas siswa yaitu meningkatkan daya imajinasi, melatih siswa untuk mampu bekerja sendiri, dan meningkatkan siswa untuk menyukai hal-hal baru; 4) memberikan reward pada akhir pembelajaran terhadap siswa yang kreatif. Upaya-upaya yang dilakukan guru untuk memperbaiki kreativitas siswa pada siklus I tersebut mampu meningkatkan setiap aspek kreativitas siswa pada siklus II. Terjadi peningkatan pada setiap indikator kreativitas siswa dari siklus I ke siklus II. Suatu tindakan dikatakan berhasil apabila mampu mencapai kriteria yang telah ditentukan. Keberhasilan tindakan dalam penelitian ini ditentukan pada peningkatan komponen yang diamati pada setiap akhir siklusnya, dalam hal ini ditentukan kriteria $\geq 76 \%$ dengan kategori baik dan sangat baik. Kategori kriteria keberhasilan yang digunakan pada penelitian ini adalah berikut: a) kategori kurang sekali memilki skor $\leq 54 \%$; b) kategori kurang memiliki skor $55-59 \%$; c) kategori cukup memiliki skor $60-75 \%$; d) kategori baik memiliki skor 76-85\%; dan e) kategori sangat baik memiliki skor $86-100 \%$.

Rata-rata persentase indikator kreativitas siswa pada siklus I adalah $74,95 \%$ dengan kategori cukup baik sehingga siklus I dinyatakan belum berhasil. Peningkatan berlanjut pada siklus II yaitu mencapai $87,81 \%$ dengan kategori baik sehingga mencapai kriteria keberhasilan yang telah ditetapkan yaitu $\geq 76 \%$ dan dapat dinyatakan berhasil. Pada siklus II rata-rata persentase kreativitas siswa adalah $87,81 \%$ atau meningkat sebesar $12,86 \%$ dari siklus I. pemanfaatan koperasi sekolah terbukti dapat meningkatkan kreativitas siswa kelas VII 2 SMP Negeri 3 Banjar.

\section{Koperasi sekolah bermanfaat sebagai sumber belajar IPS dalam pengembangan materi pembelajaran IPS kelas VII di SMP Negeri 3 Banjar}

Model pengintegrasian meteri yang dianggap sesuai dengan dimanfaatkannya koperasi sekolah sebagai pengembangan materi ajar adalah model pengintegrasian materi berdasarkan potensi utama. Alasan utamanya yaitu sesuai dengan hasil observasi dokumen silabus, kompetensi inti dan kompetensi dasar serta lingkup materi ajar, didapatkan hasil bahwa materi ajar pada kurikulum 2013 berbasis pada tema. Karena sudah berbasis tema, maka pengintegrasian materi ajar dengam memanfaatkan koperasi sekolah dijadikan sebagai lingkungan potensial dalam rangka pengembangan materi ajar daklam bentuk handout materi dan RPP. Selain itu, Depdiknas (2007) menyatakan bahwa dengan model pengintegrasian materi berdasrkan potensi utama, diharapkan dapat mengkaji potensi yang ada di lingkungan siswa, sehngga siswa atau peserta didik dapat lebih memahami kondisi daerah atau lingkungannya sekaligus memahami kompetensi dasar pada mata pelajaran IPS. 
Berkaitan dengan penyusuan handout materi ajar dan RPP yang mengintegrasikan koperasi sekolah, penilaian dilaksanakan oleh ahli pengembangan produk berupa handout dan praktisi guru IPS di SMP Negeri 3 Banjar. Beberapa masukan dari ahli terkait penyusunan handout materi adalah 1). Contoh-contoh kontektual dengan koperasi sekolah agar diperkaya di handout dan 2). Teknik penyajian agar lebih menarik. Masukan dari praktisi guru IPS di SMP Negeri 3 banjar yaitu 1) Handout materi yang dikembangkan agar dibuat lebih ringkas dan 2). Materi yang dikembangkan harus lebih ditekankan pada materi ajar.

Berdasarkan beberapa masukan tersebut, handout materi pengembangan selanjutnya kembali direvisi. Setelah melewati tahap revisi, produk pengembangan berupa handout materi dan RPP dinilai kelayakannya oleh ahli dan praktisi guru IPS. Hasil penilaian menunjukkan bahwa handout materi dan RPP termasuk kategori baik dengan keterangan revisi seperlunya. Beberapa indikator penilaian handout materi yang perlu disempurnakan kembali adalah indicator materi, kegiatan pembelajaran dan alokasi waktu.

Pengembangan handout materi IPS yng dilaksanakan oleh Apsari (2016) dan Sebo (2016) pada penelitian sebelumnya, juga diperoleh hasil uji terkategori baik. Hal tersebut mengidikasikan bahwa produk yang dikembangkan masih perlu dikembangkan lebih baik lagi dengan harapan produk yang dibuat dan dikembangkan selanjutnya lebih mampu dan lebih efektif meningkatkan tidak hanya proses dan hasil belajar tetapi pada aspek lainnya.

Perolehan kategori baik pada produk hasil pengembangan berupa handout dan RPP, tidak terlepas dari adanya beberapa kekurangan yang ada pada produk pengembangan yang telah disebut sebelumnya. Indikator dengan beberapa aspek yang memperoleh skor 3 (cukup) menjadi dasar penentu produk pengembangan berupa handout materi dan RPP termasuk pada kategori baik. Hasil penilaian tersebut menunjukkan bahwa handout materi dan RPP yang dikembangkan dapat dikatakan layak untuk digunakan dan diujicoba dalam pembelajaran IPS.

Proses selanjutnya yaitu melakukan uji coba dengan menggunakan hasil belajar pengetahuan siswa. Uji coba ini terbagi menjadi 2 yaitu uji coba kelas terbatas dan uji coba lapangan dengan kelas eksperimen yang menggunakan handout materi ajar dan kelas kontrol yang tidak menggunakan handout materi ajar. Rentangan nilai 56-70 bahwa mengalami peningkatan nilai dalam melakukan uji coba kelas terbatas dengan uji kelas Kontrol dengan selisih rata-rata 3,01 . Uji kelas eksperiman rata-rata nilai pada rentangan nilai kisaran 71-85, serta tidak ada siswa yang memperoleh nilai pada rentang $0-55$. Hal tersebut mengidentifikasi bahwa kemampuan siswa dari pengembangan materi ajar tergolong baik.

\section{SIMPULAN DAN SARAN}

Berdasarkan analisis data dan pembahasan, maka dapat disimpulkan:

1. Nilai-nilai karakter koperasi sekolah atau koperasi siswa (Kopsis) yang ditanamkan kepada siswa diantaranya (1). Pembukuan atau pencatatan transaksi secara jujur dan terbuka (2) Memupuk rasa tanggungjawab melalui penyelenggaraan laporan pertanggungjawaban pengelolaan kopsis pada setiap akhir tahun yang disampaikan dalam forum Rapat Anggota Tahunan (RAT). (3). Menumbuhkan kepedulian antar siswa. (4). Meningkatkan semangat kekeluargaan sesama siswa.

2. Hasil pengamatan dari keseluruhan indikator pada siklus I menunjukkan kreativitas siswa belum mencapai kriteria keberhasilan yang diinginkan. Sebanyak 11 aspek kreativitas siswa yang belum dapat tercapai. Hasil persentase yang diperoleh dari pengamatan kreativitas siswa masih kurang dari $76 \%$ yaitu $74,95 \%$, sehingga belum mencapai kriteria keberhasilan yang diinginkan.

3. Hasil observasi keaktifan siswa pada siklus II, menunjukkan bahwa pada setiap indikator kreativitas siswa pada setiap pertemuan sudah mengalami peningkatan dalam indicator keberhasilan yang telah ditetapkan sebesar $\geq 76 \%$. Hasil persentase untuk keseluruhan indikator kreativitas diatas menunjukkan rata-rata kreativitas siswa pada siklus II sebesar $87,81 \%$. 
4. Penelitian dan pengembangan ini menghasilkan produk berupa pemanfaatan koperasi sekolah sebagai sumber belajar IPS pada SMP Negeri 3 Banjar. Tahapan yang dilakukan sebagai berikut: a) tahap pengumpulan informasi; b) tahap perencanaan; c) tahap pengembangan; dan d) tahap validasi dan uji coba.

5. Persentase keseluruhan tersebut merupakan hasil akhir yang dijadikan dasar penentuan kualifikasi kategori produk yang telah dibuat dan divalidasi oleh ahli. Proses perhitungan memperoleh persentase keseluruhan sebesar $77,27 \%$. Berdasarkan hasil tersebut, maka pengembangan handout materi yang memanfaatkan koperasi sekolah sebagai sumber materi ajar IPS, termasuk kategori baik dengan keterangan direvisi seperlunya.

6. Hasil perhitungan diperoleh persentase keseluruhan sebesar 77,94\%. Artinya, pengembangan RPP dengan pengintegrasian handout materi yang memanfaatkan koperasi sekolah sebagai sumber materi ajar IPS di SMP Negeri 3 Banjar, termasuk kategori baik dengan keterangan direvisi seperlunya.

7. Rentangan nilai 56-70 bahwa mengalami peningkatan nilai dalam melakukan uji coba kelas terbatas dengan uji kelas control dengan selisih rata-rata 3,01. Uji kelas eksperiman rata-rata nilai pada rentangan nilai kisaran $71-85$, serta tidak ada siswa yang memperoleh nilai pada rentang 0-55. Hal tersebut mengidentifikasi bahwa kemampuan siswa dari pengembangan materi ajar tergolong baik.

Berdasarkan hasil penelitian dan pengembangan ini, maka dapat disarankan hal-hal sebagai berikut:

1. Siswa

Siswa diharapkan dapat mengembangkan wawasan, pengetahuan khususnya dalam pembelajaran IPS untuk dapat mengembangkan nilai-nilai dan meningkatkan kreativitas di sekolah.

2. Guru

Mengingat hasil produk penelitian dan pengembangan dapat memberikan manfaat bagi pembelajaran, maka disarankan kepada guru untuk mengembangkan produk ini dengan cakupan yang lebih luas ataupun pada materi lain, bahkan pada mata pelajaran lain pada waktu yang mendatang.

3. Sekolah

Secara bertahap sekolah diharapkan dapat menyediakan sarana dan prasarana secara lengkap sebagai sumber belajar IPS di sekolah yang dapat mengembangkan nilai-nilai siswa dalam pembelajaran IPS. Selain itu juga harus meningkatkan kualitas guru, pihak sekolah perlu menyikapi berbagai kendala yang terjadi dalam proses pembelajaran agar siswa tidak belajar monoton dan siswa dapat meningkatkan kreativitas.

4. Perguruan Tinggi

Perlu adanya penelitian lebih lanjut seperti penelitian tindakan kelas ataupun penelitian pengembangan lebih lanjut untuk benar-benar mengukur efektivitas penggunaan produk, mengukur peningkatan tingkat pencapaian keseluruhan hasil belajar siswa mencakup aspek kognitif, afektif dan psikomotor serta memperbanyak fakta uji lapangan sehingga diperoleh lebih banyak bahan untuk memperbaiki produk dan pada akhirnya produk yang dihasilkan akan lebih baik lagi.

\section{DAFTAR RUJUKAN}

Candiasa, I.M. 2010. Pengujian Instrument Penelitian Disertai Aplikasi Human Dan Bigsteps. Singaraja: Unit Penerbitan Universitas Pendidikan Ganesha.

Candiasa, I.M. 2011. Pengujian Instrument Penelitian Disertai Aplikasi Human Dan Bigsteps. Singaraja: Unit Penerbitan Universitas Pendidikan Ganesha.

Depdiknas. 2006. Model Pembelajaran Terpadu Ilmu Pengetahuan Sosial SMP/MTS/SMPLB. Jakarta. Badan Penelitian Dan Pengembangan Nasional. Aplikasi. Bandung: Alfabeta. 
PIPS, Vol. 2 No. 2, Bulan April Tahun 2018

Depdiknas. 2008. Kamus Besar Bahasa Indonesia Pusat Bahasa. Jakarta: PT Gramedia Pustaka.

Sanjaya, Wina. 2010. Strategi Pembelajaran Birorientasi Standar Proses Pendidikan. Jakarta: Prenada Media Group.

Sugiyono. 2010. Metode Penelitian Pendidikan Pendekatan Kuantitatif, Kualitatif Dan R\&D. Bandung: Alfabeta

Undang-Undang Republik Indonesia Nomor 25 Tahun 1992 Tentang Perkoperasian. 1992. Jakarta. 